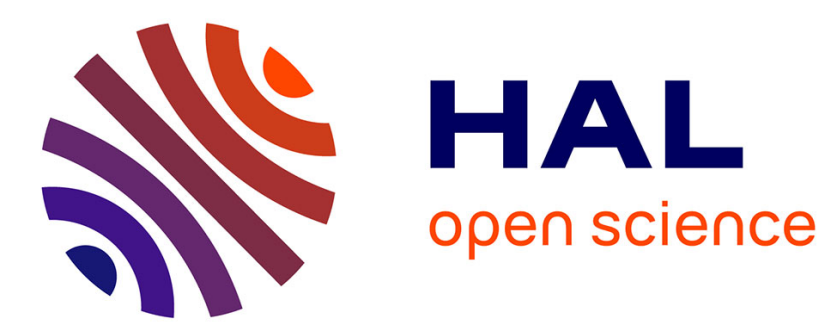

\title{
Application of new assays for rapid confirmation and genotyping of isolates of rubella virus
}

Yan Feng, Sabine Santibanez, Hazel Appleton, Yiyu Lu, Li Jin

\section{To cite this version:}

Yan Feng, Sabine Santibanez, Hazel Appleton, Yiyu Lu, Li Jin. Application of new assays for rapid confirmation and genotyping of isolates of rubella virus. Journal of Medical Virology, 2010, 83 (1), pp.170. 10.1002/jmv.21941 . hal-00599786

\section{HAL Id: hal-00599786 \\ https://hal.science/hal-00599786}

Submitted on 11 Jun 2011

HAL is a multi-disciplinary open access archive for the deposit and dissemination of scientific research documents, whether they are published or not. The documents may come from teaching and research institutions in France or abroad, or from public or private research centers.
L'archive ouverte pluridisciplinaire HAL, est destinée au dépôt et à la diffusion de documents scientifiques de niveau recherche, publiés ou non, émanant des établissements d'enseignement et de recherche français ou étrangers, des laboratoires publics ou privés. 


\section{Application of new assays for rapid confirmation and genotyping of isolates of rubella virus}

\begin{tabular}{|r|l|}
\hline Journal: & Journal of Medical Virology \\
\hline Manuscript ID: & JMV-10-1807.R2 \\
\hline Wiley - Manuscript type: & Research Article \\
\hline Author: & 28-Jul-2010 \\
\hline Complete List of Authors: & $\begin{array}{l}\text { Feng, Yan; Centre for Disease Control and Prevention of Zhejiang } \\
\text { Province; Centre for Infections, Health Protection Agency Centre for } \\
\text { Infections, Health Protection Agency } \\
\text { Santibanez, Sabine; Robert Koch-Institut } \\
\text { Appleton, Hazel; Centre for Infections, Health protection Agency } \\
\text { Lu, Yiyu; Centre for Disease Control and Prevention of Zhejiang } \\
\text { Province } \\
\text { Jin, Li; Health protection Agency, Virus Reference Department }\end{array}$ \\
\hline Keywords: & \begin{tabular}{l} 
rubella virus isolates, PCR assays, genotyping \\
\hline
\end{tabular} \\
\hline
\end{tabular}

\section{SCHOLARONE ${ }^{\text {M }}$ Manuscripts}


2 Application of new assays for rapid confirmation and

3 genotyping of isolates of rubella virus

4

$5 \quad$ Yan Feng ${ }^{1,2}$, Sabine Santibanez ${ }^{3}$, Hazel Appleton ${ }^{2}$, Yiyu Lu ${ }^{1^{\star}}$, Li Jin $^{2^{\star}}$

6

$7 \quad{ }^{1}$ Institute of Viral Diseases, Centre for Disease Control and Prevention of

$8 \quad$ Zhejiang Province, Hangzhou, China

$9 \quad{ }^{2}$ Virus Reference Department, Centre for Infections, Health Protection Agency,

10 London, UK

$11{ }^{3}$ National Reference Centre for Measles, Mumps and Rubella, Department of

12 Viral Infections, Robert Koch-Institut, Berlin, Germany

15 'Correspondence to

16 Dr. Li Jin, Virus Reference Department, Centre for Infections, Health Protection Agency,

17 61Colindale Avenue, London NW9 5EQ, UK. E-mail: li.jin@hpa.org.uk

18 Dr. Yiyu Lu, Institute of Viral Diseases, Centre for Disease Control and Prevention of

19 Zhejiang Province, 630 Xin Cheng Road, Hangzhou 310051, China.

20 E-mail: luyiyuzjh@yahoo.com.cn 
1 Abstract

2 Rubella virus (RV) isolation is recommended by the WHO Measles and Rubella

3 Labnet for studying the aetiology and epidemiology of rubella. However, the

4 absence of cytopathologic effects (CPE) in many of the cell lines used commonly

5 makes it difficult to confirm RV growth. In this study, two assays amplifying RV

6 cDNA were developed and validated in order to confirm and genotype RV

7 isolates after cell culture. A SYBR Green I-based real-time PCR (Rtime-SGE317)

8 was established for initial rapid detection of RV in Vero cells and a nested PCR

9 (PCR-E860) was used for amplifying further the 739nt window of the E1 gene for

10 identification of RV genotype as recommended by the WHO. Sensitivities of the

11 two assays were evaluated using eight RV isolates, two from infants with the

12 congenital rubella syndrome (CRS) and six from patients with acute rubella. All

13 the isolates had cycle threshold $(\mathrm{Ct})$ values $<37$ after the third passage, which is

14 recommended as the cut-off for confirmation of a viable RV isolate. Phylogenetic

15 analysis based on the 739nt window generated by the PCR-E860 showed that

16 the eight $R V$ isolates belonged to genotypes $1 E, 1 G$ and $2 B$. The Rtime-SGE317

17 assay can be carried out in local public health laboratories, which would extend

18 the molecular surveillance of rubella and contribute to the WHO goal of

19 eradicating rubella worldwide.

22 KEY WORDS: rubella virus isolates; PCR assays; genotyping 


\section{INTRODUCTION}

2 Rubella is a mild, sub-clinical disease with few complications, but infection

3 during early pregnancy can lead to severe birth defects known as congenital

4 rubella syndrome (CRS) [Best and Enders, 2007; WHO,2000]. Since the

5 introduction of rubella vaccination, the incidence of rubella has been reduced

6 greatly and CRS is very rare in countries, such as the United Kingdom and the

7 United States of America, which have established rubella vaccination

8 programmes [WHO, 2000]. In 2007, 975 suspected cases of CRS were reported

9 from 34 countries in the western hemisphere where CRS surveillance has been

10 established [WHO, 2008]. The World Health Organization (WHO) has estimated

11 that more than 100,000 cases of CRS occur in developing countries every year

12 [WHO, 2000]; this represents a considerable social and economic burden.

13 Rubella is regarded as another target for eradication in countries where

14 transmission of measles virus has already been interrupted [WHO, 2000].

16 Rubella virus (RV), the sole member of the genus Rubivirus of the family

17 Togaviridae, is a positive single stranded RNA virus [Chantler et al., 2001]. The viral genome encodes five proteins, two non-structural proteins (P90 and P150) and three structural proteins (E1, E2 and the capsid protein). Major neutralizing and haemagglutinating epitopes and T cell recognized sites are located in the structural proteins [Chantler et al., 2001; Cordoba et al., 2000]. The high $\mathrm{G}+\mathrm{C}$ content, of up to $65 \%$, is the most significant characteristic of the viral genome,.

Clinical diagnosis of rubella is unreliable and therefore laboratory confirmation is necessary, particularly for the diagnosis of rubella-like illness during pregnancy. 
1 Serological diagnosis, by the detection of rubella-specific immunoglobulin $M$

2 ( $\operatorname{lgM})$ in a single serum or oral fluid sample, is the common method for

3 confirming rubella cases, and has proved a good indicator for demonstrating

4 recently acquired infection [Banatvala and Brown, 2004]. Prenatal diagnosis of

5 rubella infection based on rubella specific $\lg M$ alone is unreliable until at least 22

6 weeks gestation [Enders and Jonatha, 1987].

7

8 Virus isolation is a conventional laboratory method, and important for monitoring

9 virus excretion in CRS infants. Although virus isolation is time-consuming,

10 labour-intensive and not particularly sensitive, it is still recommended by the

11 WHO for studying the aetiology and epidemiology of rubella [WHO, 2007]. RV

12 can be cultured in a variety of cell lines, such as RK13, SIRC, BHK and Vero

13 (Vero/SLAM) cells, but serial propagation can be established only in a limited

14 number of cell lines [Figueiredo et al., 2004]. Previous studies have shown that

15 specific CPE may appear in RK13 cells under controlled conditions, or in RK13

16 and SIRC cells after one or two passages in Vero cells [Figueiredo et al., 2000;

17 Best et al., 2005].

19 The immunofluorescence assay (IFA) is a conventional method for confirming

20 rubella growth, but it is time-consuming, relies on the operator's interpretation

21 and requires a fluorescence microscope. Recently, the reverse-transcriptase

22 polymerase chain reaction (RT-PCR) followed by hybridisation assays, the

23 replicons-based method and the indirect immunocolorimetric assay (ICA) have

24 been developed to detect rubella virus infected cells [Zhu, et al. 2007; Chen, et

25 al. 2007]. 
2 Genetic characterization of virus isolates has relied on nested RT-PCR assays to

3 generate the $739 \mathrm{nt}$ region of the $\mathrm{E} 1$ gene that is required for genotyping in

4 accordance with the recommendations of the WHO [WHO, 2005]. In this study, a

5 SYBR Green I-based real-time PCR assay (Rtime-SGE317) was developed,

6 initially at Health Protection Agency in the UK (WHO Rubella Strain Bank), and

7 applied subsequently to rapid confirmation of RV isolates by testing samples of

8 tissue culture fluid from Vero cells at the Centre for Disease Control and

9 Prevention of Zhejiang Province, China. Compared with other methods, namely

10 IFA and electron microscopy (EM), the Rtime-SGE317 can be carried out easily

11 at local public health laboratories. The nested PCR (PCR-E860), developed

12 initially at the Robert Koch-Institut, was used both at the Health Protection

13 Agency and the Centre for Disease Control and Prevention of Zhejiang Province

14 to generate the required $\mathrm{E} 1-739$ nt region from eight confirmed $\mathrm{RV}$ isolates for

15 genotyping. By combining the two assays, RV isolates could be confirmed and

16 genotyped very quickly. These two tests offer the opportunity of extending the

17 molecular surveillance of rubella and contributing to the WHO goal of eradicating

18 rubella worldwide. 
1 MATERIALS AND METHODS

2 Specimens

3 Eight $\mathrm{RV}$ isolates were investigated in the study. Two $(\mathrm{H} 1$ and $\mathrm{U} 6)$ were isolated

4 from nasal and throat swab specimens of two Sudanese infants with

5 serologically confirmed CRS [Omer et al., 2010]. These two isolates were also

6 used for comparing the PCR assays developed in this study with other detection

7 methods, EM and IFA (Table II ). The other six (ZJ1 ZJ6) were isolated originally

8 at the Centre for Disease Control and Prevention of Zhejiang Province, China

9 between 2005 and 2008 from throat swab specimens collected from patients

10 with acute rubella confirmed serologically.

12 Virus isolation and blind passages

13 Vero cells were seeded at a concentration of $5 \times 10^{5}$ cells $/ \mathrm{ml}$ in glass tubes.

14 Growth medium (GM) was Dulbecco's MEM (DMEM) containing 5\% foetal

15 bovine serum (FBS), $50 \mu \mathrm{g} / \mathrm{ml}$ gentamicin and an additional 200mM L-glutamine.

16 Cells were incubated at $37^{\circ} \mathrm{C}$. Once a monolayer of cells had formed, the GM

17 was removed and the cells inoculated with $100 \mu$ l clinical specimen and left for

18 one hour at $37^{\circ} \mathrm{C} . \quad 0.9 \mathrm{ml}$ maintenance medium (MM) containing $2 \%$ FBS was

19 then added to the monolayer and the tubes were incubated stationary at $37^{\circ} \mathrm{C}$.

20 The cells were observed daily. After seven days the tubes were frozen at $-80^{\circ} \mathrm{C}$

21 for one to two hours. After thawing, the cells were scraped into the culture

22 medium, thoroughly mixed and then centrifuged at $200 \times \mathrm{g}$ for $10 \mathrm{~min}$.

23 Supernatant and cells were harvested separately as the $1^{\text {st }}$ passage. $100 \mu$ l cells

24 and supernatant were passaged separately into fresh Vero cells to the $5^{\text {th }}$

25 passage. 


\section{RNA extraction and reverse transcription}

2 Total RNA was extracted from $100 \mu$ l tissue culture fluid supernatant/cells using

3 the MagNA Pure extractor (Roche, UK). In a $50 \mu$ l reaction mixture, a $20 \mu \mathrm{l}$ sample of RNA was reverse transcribed to CDNA using random primers as described previously [Cooray et al., 2006; Vyse and Jin, 2002].

7 Alternatively, total RNA was extracted using the RNeasy Mini Kit (Qiagen,

8 Germany). $200 \mu$ lissue culture fluid mixture was extracted and eluted into $50 \mu \mathrm{l}$

9 RNase-free water. cDNA was generated using M-MLV Reverse transcriptase

10 (Invitrogen or Promega) and either the specific primer Ru1r for the PCR-E860 or

11 random primers for both the nested PCR-E860 and Rtime-SGE317. The $10 \mu \mathrm{l}$

12 reaction mixture contained $2.5 \mu$ l sample RNA.

14 At the Robert Koch-Institut, total RNA was extracted from $140 \mu$ lissue culture fluid using the QIAamp Viral RNA Mini kit (Qiagen, Germany) and was eluted

16 into $60 \mu \mathrm{l}$ RNase-free water. A $2.5 \mu$ l sample RNA was used to generate cDNA 17 using the specific primer Ru1r.

SYBR Green I-based real-time PCR assay for rubella virus (Rtime-SGE317)

20 The primer pair of E1.7 and E1.8, which is used routinely as a part of the nested

21 PCR-E317 assay at the Health Protection Agency and as described previously

22 [Jin and Thomas, 2007], was adapted. The primer concentration was optimised at a range of $0.5-1.0 \mu \mathrm{M}$. The reaction with a final concentration $1.0 \mu \mathrm{M}$ gave the best result for both sensitivity and specificity (results not shown). The assay was performed using the QuantiTect SYBR Green PCR kit (Qiagen, Germany) on a 
$1 \quad$ LightCycler 2.0 (Roche, Switzerland). Each $20 \mu$ l reaction mixture contained $10 \mu \mathrm{l}$

2 of $2 x$ SYBR Green I buffer, $0.2 \mu \mathrm{l}$ of each primer (100pmol/ $\mu \mathrm{l}), 7.6 \mu \mathrm{l} \mathrm{dH}_{2} \mathrm{O}$ and

$32 \mu \mathrm{l}$ cDNA or plasmid DNA. The Tm of the specific product amplified was $89^{\circ} \mathrm{C}$

4 according to the melting curve, and therefore a fourth step of incubating at $82^{\circ} \mathrm{C}$

5 for $5 \mathrm{sec}$ was added to eliminate the effect of non-specific amplification. The

6 optimised amplification conditions are shown in Table I .

7

8 Sensitivity of the Rtime-SGE317 was evaluated using serial diluted plasmid DNA

9 of the E1 gene containing both the window 739nt and the target of the

10 Rtime-SGE317, and the random primer generated cDNA of the Thomas strain of

11 rubella (used routinely as a positive control at the Health Protection Agency).

12 The plasmid DNA used as standards for quantitation was diluted serially from $10^{6}$

$13 \mathrm{copies} / \mu \mathrm{l}$ to 10 copies/ $\mu$ l. Standard curves were plotted with related copy

14 numbers, and the reproducibility of the assay for RV genome detection was

15 quantified in triplicate using tissue culture fluid samples of four RV isolates ZJ1-4

16 (Table II).

17

\section{Nested PCR-E860 for rubella virus (PCR-E860)}

19 The nested PCR assay (PCR-E860) was developed initially at the Robert

20 Koch-Institut. The primers for the first round, Ru1r (5'-CTG CCG GGT CTC CGA

21 CAC AGC) and Ru2f (5'-GAC ACC GTG ATG AGC GTG TTC), and for the

22 nested round, Ru3r (5'-GTG GTG TGT GTG CCA TAC AC) and Ru4f (5'-CTT

23 GCT AGC TAC GTC CAG CAC) generate a 860nt fragment of RV E1 gene

24 (nt8687-9546, Genbank accession number L78917), covering the 739nt window

25 (E1 nt8731-9469) as recommended by the WHO for genotyping. In a total 
1 volume of $25 \mu \mathrm{l}$ per reaction, $2.5 \mu \mathrm{l}$ (Robert Koch-Institut, Centre for Disease

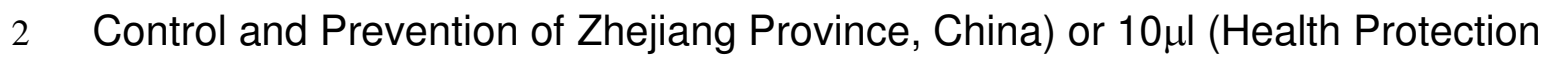

3 Agency) cDNA was added as the template for the first round PCR. $2 \mu \mathrm{L}$ (Robert

4 Koch-Institut and Centre for Disease Control and Prevention of Zhejiang

5 Province, China) or $4 \mu \mathrm{l}$ (Health Protection Agency) of the first round amplicon

6 was used for the nested PCR-E860 assay. The PCR amplification conditions for

7 both first and second rounds are shown in Table I .

8

9 Sequencing for RV genotyping

10 The products of Rtime-SGE317 and the nested PCR-E860 were purified using

11 the MinElute PCR Purification Kit (Qiagen, Germany) and then sequenced by

12 commercial companies (Invitrogen Com Ltd, Shanghai, China; MWG, Germany).

13 The primers E1.7 and E1.8 for the amplicons of the Rtime-SGE317 and primers

14 Ru3r and Ru4f for the amplicons of the nested PCR-E860 were used for

\section{sequencing. The phylogenetic trees were constructed using DNAStar software} on the basis of either the $280 \mathrm{nt}$ or $739 \mathrm{nt}$ sequences.

\section{Indirect Immunofluorescence assay (IFA)}

The medium was removed from infected Vero cells and the cells were washed gently with PBS. The PBS was removed and $0.25 \%$ Typsin-EDTA was added so as to just cover the cell monolayer and left for 30 seconds. After a low speed spin, the cells were re-suspended in PBS to the required cell density. The cells were fixed on slides at $-20^{\circ} \mathrm{C}$ for 20 min with methanol and acetone (1:1), then $1: 100$ dilution mouse monoclonal antibodies containing anti-rubella capsid protein $\mathrm{C}$ (provided by CDC, USA) and anti-structural glycoprotein E1 (gifted by Dr. D 
1 Samuel, Microlmmune, UK) was added and incubated at $37^{\circ} \mathrm{C}$ for $20 \mathrm{~min}$. After

2 washing with PBS and deionised water, 1:20 diluted FITC-goat anti-mouse

$3 \lg \mathrm{G}+\mathrm{M}+\mathrm{A}$ antibody (Invitrogen) was applied for $20 \mathrm{~min}$ at $37^{\circ} \mathrm{C}$. Negative and

4 positive control slides were prepared and observed at the same time according

5 to the WHO manual [WHO, 2007].

6

$7 \quad$ Electron microscopy (EM)

8 Rubella is a fragile virus morphologically. Therefore, cultures were fixed prior to

9 processing, by adding Carson's buffered formaldehyde (Bios Europe Ltd) to give

10 a final concentration of $1.5 \%(\mathrm{v} / \mathrm{v})$ formaldehyde in the culture medium, and

11 stored at $40 \mathrm{C}$ until examined. Cells were scraped into the medium and the

12 mixture of cells and tissue culture fluid was centrifuged at $48000 \times \mathrm{g}$ for $45 \mathrm{~min}$.

13 The supernatant was discarded and the pellet re-suspended in distilled water.

14 The suspension was treated in an ultrasonic bath to break up clumps of cells. A

15 drop of suspension was stained with phosphotungstic acid (PTA) pH6.8 and

16 placed on a formvar-carbon coated EM grid. Grids were examined in a Philips

17420 transmission electron microscope fitted with an AMT XR60 digital imaging

18 system.

19 


\section{RESULTS}

2 Specificity, sensitivity and reproducibility of the Rtime-SGE317

3 The Rtime-SGE317 was developed to replace the probe-based real-time PCR

4 assay used previously [Jin and Thomas, 2007]. The new assay had the

5 advantage of being rapid and specific for confirmation of $\mathrm{RV}$ isolates. Even

6 though the primer pair gave consistent results with different RV strains,

7 specificity of the assay was evaluated further with measles virus and B19 virus,

8 which cause similar symptoms to rubella. Measles cDNA and B19 DNA were

9 tested by Rtime-SGE317 and all samples were negative with no cross-reactions

10 (results are not shown). The time taken to perform the Rtime-SGE317 assay was

112.5 hours less than for the previous assays (Table I ). Sensitivity of the

12 Rtime-SGE317 was also compared with nested PCR-E317 and nested

13 PCR-E860. The Rtime-SGE317 detected 200 copies/reaction of plasmid DNA

14 (Table I ).

16 The tissue culture fluid samples from four Chinese strains (ZJ1-4) were tested in

17 triplicate to evaluate the reproducibility of the assay. Table II showed that the Ct

18 values differed by less than one within each sample, whereas the deviation

19 based on the copy numbers ranged from 4.6 to 18.3 times, e.g. strain ZJ1 and

20 ZJ3 (indicated in italic in Table II ). Correlation between Ct values and copy

21 numbers was plotted using the data collected from all samples and RV plasmid

DNA tested in this study. The samples with $C t$ value $>/=40$ were defined as negative, though high copy numbers up to $\sim 10,000$ copies were estimated based on the standards (Figure 1). Figure 1 shows that distribution of copy numbers was much wider when Ct values were $>20$ or copy numbers $<10^{6}$, 
1 which indicated that Ct value was more stable and reliable for estimation of viral

2 load in cell cultures.

3

4 Comparison of the methods for confirmation of RV isolates

5 The tissue culture fluids collected from the first to fifth passage of two RV

6 isolates from CRS patients ( $\mathrm{H} 1$ and $\mathrm{U} 6)$ were tested by three methods, IFA, EM

7 and the Rtime-SGE317 (Table II ). Clinical specimens from the two cases of CRS

8 were inoculated and passaged up to four rounds (the harvest from the last one

9 named as the $5^{\text {th }}$ passage, P5). Specimens were incubated in Vero cells for

10 7days each passage, but specific CPE was not clearly apparent. The infected

11 cells collected from the $2^{\text {nd }}$ to $5^{\text {th }}$ passage were tested by IFA and EM. Weak

12 fluorescence was observed in the $2^{\text {nd }}$ passage. Fluorescence became stronger

13 with passage affecting about $30 \%$ cells in the $3^{\text {rd }}$ passage and $50 \%$ in the $5^{\text {th }}$

14 passage.

16 RV particles were not observed by EM in the $2^{\text {nd }}$ passage, but small groups of 17 particles were seen in the $3^{\text {rd }}$ passage, and large clumps of virus particles were 18 found in the $4^{\text {th }}$ and $5^{\text {th }}$ passage (Figure 2 ). Rubella virus is usually strongly cell associated and the viral particles observed were all attached to cell debris.

21 Supernatant and cells of RV isolates were each tested quantitatively using the

22 Rtime-SGE317. RV genome was detected from the $1^{\text {st }}$ passage of sample U6

23 and the $3^{\text {rd }}$ passage of sample $\mathrm{H} 1$. Results for both $\mathrm{Ct}$ value and copy number

24 are shown in Table II. The copy numbers continually increased with each

25 subsequent passage and were higher for the cells than the supernatant. The 
1 viral load in sample U6 was much greater than in sample $\mathrm{H} 1$ in every passage,

2 which corresponds with the EM observations (Table II).

3

4 Application of the Rtime-SGE317 for confirmation and the nested

$5 \quad$ PCR-E860 for genotyping of RV isolates

6 RV isolates were obtained at the Centre for Disease Control and Prevention of

7 Zhejiang Province by inoculating throat swab specimens into Vero cells. Four

8 isolates were passaged four times (P1 to P5) and two twice only (P1 to P3). The

9 presence of RV in each passage was confirmed by detecting the RV genome

10 using the Rtime-SGE317. The six isolates were confirmed as the Ct values were

$11<35.0$ after three blind passages.

13 In order to determine the genotypes of the six Chinese isolates, the E1-739nt

14 window was amplified using the new nested PCR-E860 assay. The amplicons

15 were purified and sequenced with primers Ru3r and Ru4f. These sequences,

16 together with reference strains recommended by the $\mathrm{WHO}$, were used to

17 construct a phylogenetic tree (Figure 3). These results were in agreement with

18 those based on the 280nt products generated by Rtime-SGE317 (Results not

19 shown).

21 Based on the 739nt window of the E1 sequences (Figure 3), five isolates were assigned to genotype 1E. Isolates RVi/Zhejiang.CHN/15.05 (ZJ-1) and

$23 \mathrm{RVi} /$ Zhejiang.CHN/17.05 (ZJ-2) originating from two outbreaks in Quzhou and

24 Lishui city within two weeks of each other in 2005 were $100 \%$ identical.

$25 \mathrm{RVi} /$ Zhejiang.CHN/15.07/1 (ZJ-3) and RVi/Zhejiang.CHN/15.07/2 (ZJ-4) 
1 obtained from an outbreak in 2007 were also identical in sequence to each other,

2 but differed by 14 nt from the 2005 isolates. RVi/Zhejiang.CHN/22.08 (ZJ-5)

3 isolated in Hangzhou city in 2008 , was more closely related to the genotype $1 \mathrm{E}$

4 strain detected in Hong Kong in 2008 (RVs/HongKong.CHN/27.08-1E, GenBank

5 accession no. FJ436377). The only 2B strain RVi/Zhejiang.CHN/23.08 (ZJ-6)

6 was isolated in Lishui city in 2008, and is close (4nt differences) to the Hong

7 Kong genotype 2B isolate, RVs/HongKong.CHN/49.08-2B (GenBank accession

8 no.FJ656218).

9

10 


\section{DISCUSSION}

2 Rubella virus replicates in a variety of continuous cell lines. RK13 and SIRC cells

3 have been used because specific CPE is readily observed. However, these cells

4 do not generate high titre virus [Figueiredo, et al., 2000, Rajasundari, et al.,

5 2008]. The Vero/SLAM cell line is currently recommended by the WHO for

6 measles and rubella isolation in the Global Measles/Rubella Laboratory Network

$7 \quad[\mathrm{WHO}, 2007]$. Viral CPE is not visible in Vero/SLAM cells in most cases, even

8 after several passages. A previous study has shown that RV can replicate rapidly

9 and reach higher titres in Vero cells because they do not produce interferon

10 [Figueiredo, et al., 2000]. Therefore, the Vero cell line was used throughout this

11 study. Similar to Vero/SLAM cells, specific CPE was not visible in Vero cells

12 normally. However, it was visible when inoculated with a viral concentration of

$1310^{5} \mathrm{TCID}_{50}$ or higher [Guido et al., 1989]; or when the tissue culture fluid

14 samples of each passage harvested in the first attempt were inoculated again

15 simultaneously into fresh cells and observed in parallel which was carried out in

16 the study (result not shown). It can be difficult still to differentiate between the

17 CPE produced in infected cells and normal dead cells. Determination of RV growth after cell culture based on CPE observation alone is unreliable and subjective. Therefore, a simple method for confirmation of RV presence is

20 required. specific for confirmation of RV isolation (Table I ). It has been reported previously that the primer pair of E1.7 and E1.8 is specific and sensitive when used in a block-based nested PCR (PCR-E317) [Jin and Thomas, 2007]. The 
1 fourth step of incubating at $82^{\circ} \mathrm{C}$ for $5 \mathrm{sec}$ was added to increase the specificity. $\mathrm{A}$

2 melting curve analysis for every test is strongly recommended as it is a

3 non-probe based real-time PCR assay [Robert et al., 2009]. Even though the

4 sensitivity was 100 -fold lower than the nested PCR-E317, the Rtime-SGE317 is

5 one tenth of the cost and four times faster, and therefore suitable for rapid

6 detection of RV in large numbers of samples. The Rtime-SGE317 is less

7 sensitive compared to other real-time assays for rubella confirmation developed

8 previously in the UK or China [Jin and Thomas, 2007; Zhao et al., 2006]. This

9 could be due to its non-probe based method and the size of product. The

10 advantage of Rtime-SGE317 is that the product can be assessed quantitatively

11 and sequenced directly for confirmation and preliminary genetic classification.

12 Using plasmid DNA as standards, the viral load can be quantified based on copy

13 numbers. The copy numbers of viral load of two Sudanese isolates were higher

14 in cells than that in supernatant. Electron microscopy has confirmed that RV is

15 strongly cell associated. However, this does not mean that concentrated cells

16 are necessarily more suitable, as the remaining lysed cells may affect viral

17 propagation in fresh cells.

19 The study results show that the Ct value is more reliable than viral genome copy

20 number for estimation of viral load. The large deviation between copy numbers

21 may be caused by several factors, such as errors occurring during the manual

22 dilution and concentration measurement of the plasmid standards. In addition,

23 risk of contamination is greater using plasmid DNA. This suggests that plasmid

24 DNA as standard may not be necessary when RV isolates are confirmed by

25 Rtime-SGE317, so avoiding the risk of contamination and reducing the cost and 
1 work load at local or sub-national laboratories. By testing a serial dilution of RV

2 cDNA, it was shown that confirmation of a rubella isolate could be based on the

3 viral load when the $\mathrm{Ct}$ value was $<37$ and the amplicon is large enough for

4 sequencing the $280 \mathrm{nt}$ of the $\mathrm{E} 1$ gene. If the $\mathrm{Ct}$ value is between 37 and 40 , the

5 shape of the amplification curve should be carefully checked to ensure that the

6 sample is a real isolate. Samples with Ct value $>40$ could be passaged further,

7 but there is no point in continuing beyond the fifth passage as numbers of

8 defective virus particles may increase. Products with $\mathrm{Ct}$ value $<30$ may be

9 directly sequenced without purification.

11 Two other methods, IFA and EM, were compared with Rtime-SGE317 using the

12 two CRS isolates. IFA is a routine assay used at the Health Protection Agency

13 and is recommended by WHO. IFA indicates viable virus in cells by green

14 florescence. It is a classic assay, but requires fluorescence microscope and

15 experienced personnel to use it. The whole IFA process takes at least four hours

16 and a further PCR assay to generate the RV genome from confirmed strains for

17 genotyping. The recently developed indirect immunocolorimetric assay (ICA)

18 has the same sensitivity as IFA, and RV infected cells can be detected as

19 blue-staining spots on monolayers by the naked eye [Zhu et al., 2007; Chen et

20 al., 2007]. However, it was less sensitive than diagnostic PCR and standardised

21 high quality colorimetric reagents are not available commercially. Electron

22 microscopy requires highly experienced staff, is time consuming and is not

23 particularly sensitive. Although it can give an indication of the morphological

24 state of the viral particles, it is not suitable for rapid testing of large numbers of

25 samples. 
1 Results of phylogenetic analysis of the six Chinese RV strains supported the

2 previous suggestion that the 280 nt of $E 1$ region can be used for preliminary

3 genetic classification [WHO, 2005], especially when the 739nt window is not

4 detectable. Based on the E1-739nt window, five of the six Chinese RV strains

5 belonged to genotype1E and one to $2 \mathrm{~B}$, and the two strains isolated in 2008

6 (ZJ5-6) were close to two Hong Kong 1E and 2B isolates respectively. However,

7 there was no information available to link the viral transmissions. The results

$8 \quad$ indicated two genotypes of RV strains were co-circulating and genotype $1 \mathrm{E}$

9 could have been the dominant genotype in Zhejiang province between 2005 and

10 2008. The preliminary identified RV isolates could finally be confirmed

11 definitively by sequencing the product of the nested PCR-E860 assay, the

12 window E1-739nt, as recommended by WHO for RV genotyping [WHO, 2005].

14 In addition to rubella $\lg M$ and $\lg G$ tests, tissue culture for RV isolation is routinely

15 carried out in most of provincial laboratories and some municipal CDC

16 laboratories in China as well as in many other countries in the WHO LabNet for

17 Measles and Rubella. However, tissue culture fluid specimens have to be sent to

18 a national/regional laboratory for confirmation of RV growth because most

19 sub-national laboratories do not have a fluorescence microscope for IFA or the

20 reagents for the ICA [WHO, 2007; Zhu et al., 2007; Chen et al., 2007]. Results of

21 RV confirmation and genotyping from the national laboratory are usually

22 reported back several months later. In addition, transportation of such tissue

23 culture fluid specimens has become more complicated and costly because of

24 biological safety regulations. RV tissue culture fluid specimens cannot be sent

25 away in time for confirmation and genotyping, and RV isolation is no longer 
1 performed at some of the sub-national laboratories, which compromises rubella

2 surveillance.

3

4 Most of the sub-national laboratories in China are well equipped with real-time

5 PCR instruments and staff are well trained in performing real-time PCR assays.

6 Therefore, the Rtime-SGE317 is a viable alternative method when considering

7 costs, time available and technical skills. Since the products of Rtime-SGE317

8 can be directly sequenced, confirmation and preliminary genetic classification of

9 RV strains can be completed in the sub-national laboratories before sending to

10 the National Reference Laboratory. The remaining 50 throat swab specimens,

11 collected from 2005 to 2008 in Zhejiang province, were cultured for RV in Vero

12 cells, but were not tested locally by IFA or ICA nor sent away for confirmation.

13 These will be investigated further using the two new assays. Application of the

14 assays would improve rubella surveillance locally and speed up the

15 epidemiological reporting to national/regional Centres for Disease Control and

16 Prevention. 


\section{ACKNOWLEDGMENT}

2 The authors are grateful to Ruth Parry, Yvonne Suehong and Brain Megson

3 (Health Protection Agency) for their technical assistance, to Omer Adam (Sudan)

4 for submitting his RV isolates to WHO measles and Rubella strain Bank at

5 Health Protection Agency, and to Dr. Kevin E Brown for his critical comments

6 and support of this study. This work was supported by the Key Lab of

7 Emergency Detection for Public Health of Zhejiang Province, China and the

$8 \quad$ National Nature Science Foundation of China (project 30771903).

\section{9}

10 


\section{REFERENCES}

2 Banatvala JE, Brown DWG. 2004. Rubella. The Lancet 363:1127-1137.

3 Best JM, Cooray S, Banatvala JE. 2005. Rubella. In: Chapter 45, Virology Vol 2, Microbiology Topley \& Wilson's \& Microbial Infections, $10^{\text {th }}$ edition; Eds BWJ

$5 \quad$ Mahy \& V ter Meulen; Hodder Arnold, Inc. pp 959-992.

6 Best JM, Enders G. 2007. Laboratory Diagnosis of Rubella and Congenital

7 Rubella. In: Banatvala JE and Peckham C, editors. Perspectives in Medical

$8 \quad$ Virology-Rubella Viruses. London, Inc. pp 39-77.

9 Chantler J, Wolinsky JS, Tingle A. 2001. Rubella virus. Chapter 31. Field

10 Virology. $4^{\text {th }}$ edition. Eds Knipe DM \& Howley PM. Lippincott Williams \&

11 Wilkins, pp963-990.

12 Chen MH, Zhu Z, Zhang Y, Favors S, Xu WB, Featherstone DA, Icenogle JP.

13 2007. An indirect immunocolorimetric assay to detect rubella virus infected $14 \quad$ cells.J.Virol Methods 146:414-418.

15 Cooray S, Warrener L, Jin L. 2006. Improved RT-PCR for diagnosis and 16 epidemiological surveillance of rubella. J Clin Virol 35:73-80.

17 Cordoba P, Lanoel A, Grutadauria S, Zapata M. 2000. Evaluation of Antibodies 18 against a Rubella Virus Neutralizing Domain for Determination of Immune 19 Status. Clin and Diagn Lab Immunol 7: 964-966.

20 Enders, G., W. Jonatha.1987. Prenatal diagnosis of intrauterine rubella. Infection $15: 162-164$.

22 Figueiredo CA, Oliveira de MI, Afonso AM, Curti SP. 2004. Infectivity of wild-type 23 rubella virus in fibrochondrocyte cells. J. Bras Patol Med Lab 40:1-5.

24 Figueiredo CA, Oliveira de MI, Curti SP, Cruz AS, Moreira E, et. al. 2000. RC-IAL 
1 cell line: sensitivity of rubella virus grow. Rev Saude Publica 34:353-357.

2 Guido S, Giuseppe G, Halonen PE. 1989. Detection of rubella virus antigen by Med. Virol 29:164-169.

5 Jin L, Thomas B. 2007. Application of Molecular and Serological Assays to Case

6 Based Investigations of Rubella and Congenital Rubella Syndrome. J Med

$7 \quad$ Virol 79:1017-1024.

8 Omer A, Abdel Rahim E.-H, Ali E.-E, Jin L. 2010. Primary Investigation of 31 infants with suspected congenital rubella syndrome in Sudan. Clin Micro and Infect 16:678-682.

Rajasundari TA, Sundaresan P, Vijayalakshmi P, Brown DWG, Jin L. 2008. Laboratory confirmation of congenital rubella syndrome in infants: an eye hospital based investigation. J. Med. Virol 80:536-546.

Robert J, Pryor and Carl T. 2009. Real-Time Polymerase Chain Reaction and Melting Curve Analysis. In: Method in Molecular Biology Vol 336, Clinical Application of PCR, 2 edition. Eds Y. M. Dennis Lo, Rossa W. K. Chiu \& K. C. Allen Chan 336:19-32.

Vyse AJ, Jin L. 2002. PCR assay using oral fluid samples to detect rubella virus genome for epidemiology surveillance. Mol Cell Probes 16:93-97.

WHO. 2000. Rubella vaccine. Wkly. Epidemiol Rec. 75:161-172.

WHO. 2005. Standardization of the nomenclature for genetic characteristisation of wild-type rubella viruses. Weekly Epidemiol Rec. 80:126-132.

WHO. 2007. Manual for the laboratory diagnosis of measles and rubella virus infection. p47-94.

WHO. 2008. Progress towards eliminating rubella and congenital rubella 
1 syndrome in the western hemisphere, 2003-2008. Wkly. Epidemiol Rec.

$2 \quad 83: 395-400$.

3 Zhao LH, Ma Y, Wang H, Zhao SP, Zhao WM, et al. 2006. Establishment and

4 Application of a TaqMan Real-Time Quantitative Reverse Transcription

5 Polymerase Chain Reaction Assay for Rubella Virus RNA. Acta Biochimica et

$6 \quad$ Biophysica Sinica 38:731-736.

7 Zhu Z, Xu W, Abernathy ES, Chen MH, Zheng Q, et. al. 2007. Comparison of

8 four Methods using throat swabs to confirm rubella virus infection. J Clin

$9 \quad$ Microbiol 45: 2847-2852. 


\section{$1 \quad$ Legends for Figures}

2 Figure 1. Correlation between $\mathrm{Ct}$ and copy number when detecting RV isolates

3 by the Rtime-SGE317.

4

5 Figure. 2. Electron micrograph of rubella virus strain U6 isolated in Vero cells.

6 Virus particles can be seen closely associated with the cellular debris.

$7 \quad$ Negatively stained with phosphotungstic acid; Bar represents $100 \mathrm{~nm}$.

9 Figure 3. Genetic relationship amongst the eight RV isolates (in bold) and the

10 reference strains from Genbank based on the 739nt of the $\mathrm{E} 1$ gene sequences.

11 The phylogenetic tree was constructed using Clustal W method of the MegAlign

12 program (DNAStar $\mathrm{x} .0$ software). Eight RV isolates in this study were bolded and

13 the reference strains downloaded from GenBank were indicated with genotype

14 at the end of strain name. 
Figure 1

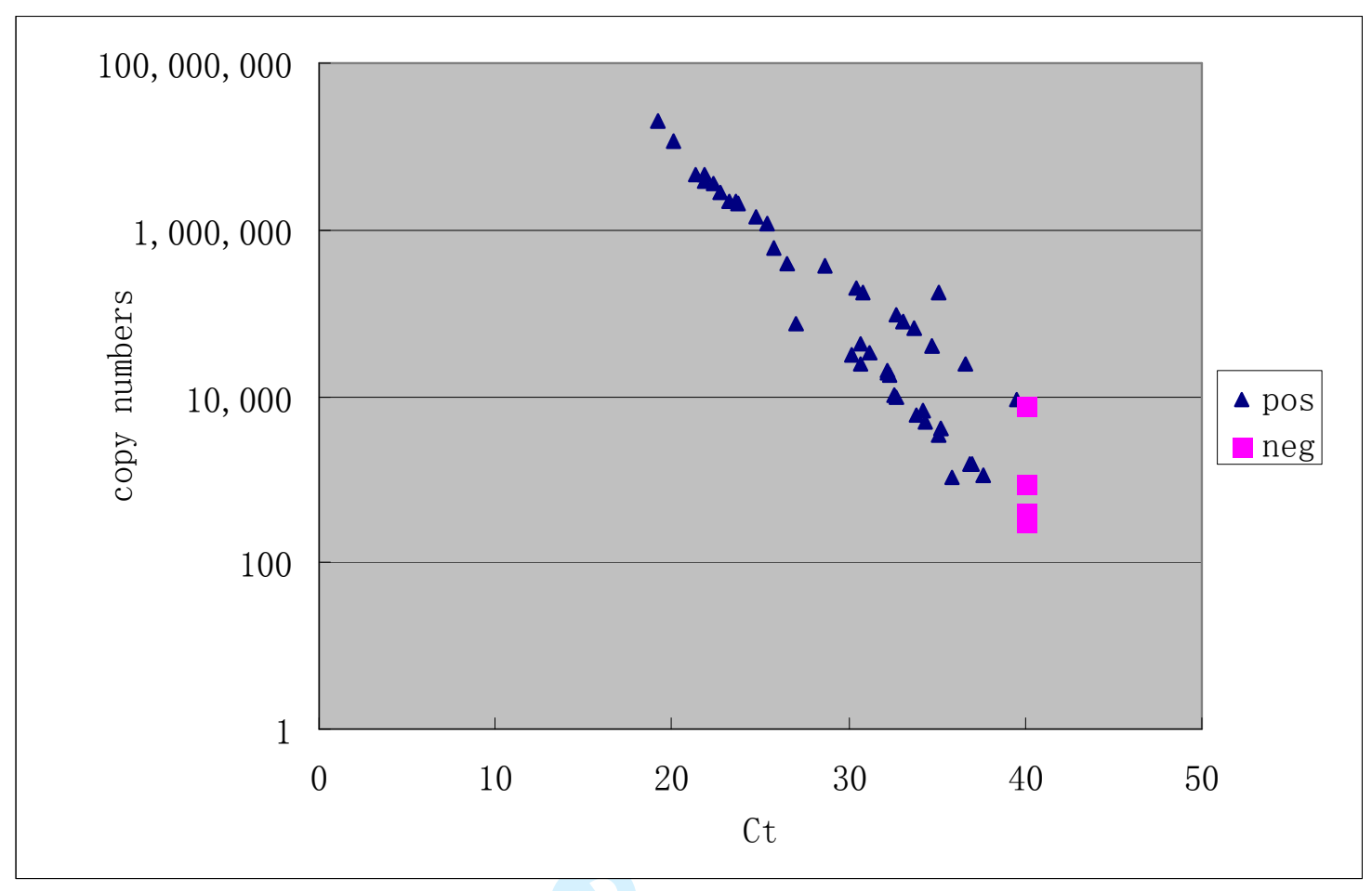

3

4

\section{$5 \quad$ Figure 2}

6

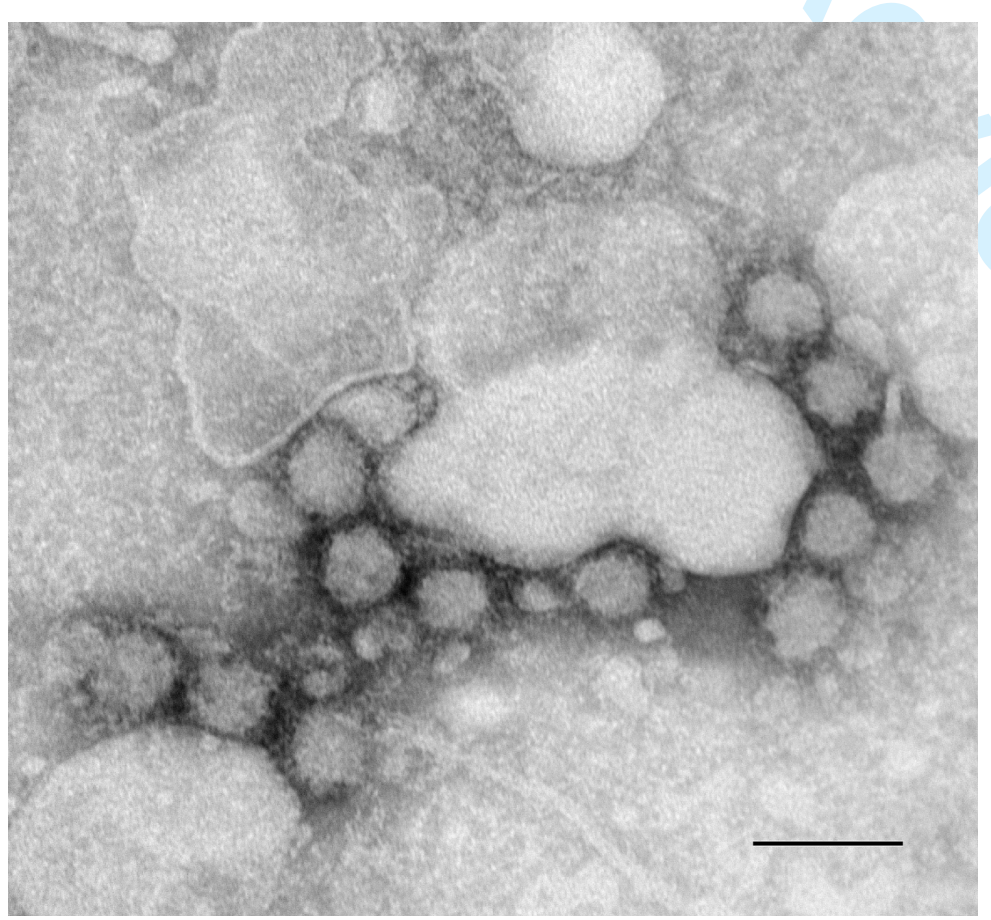


Figure 3

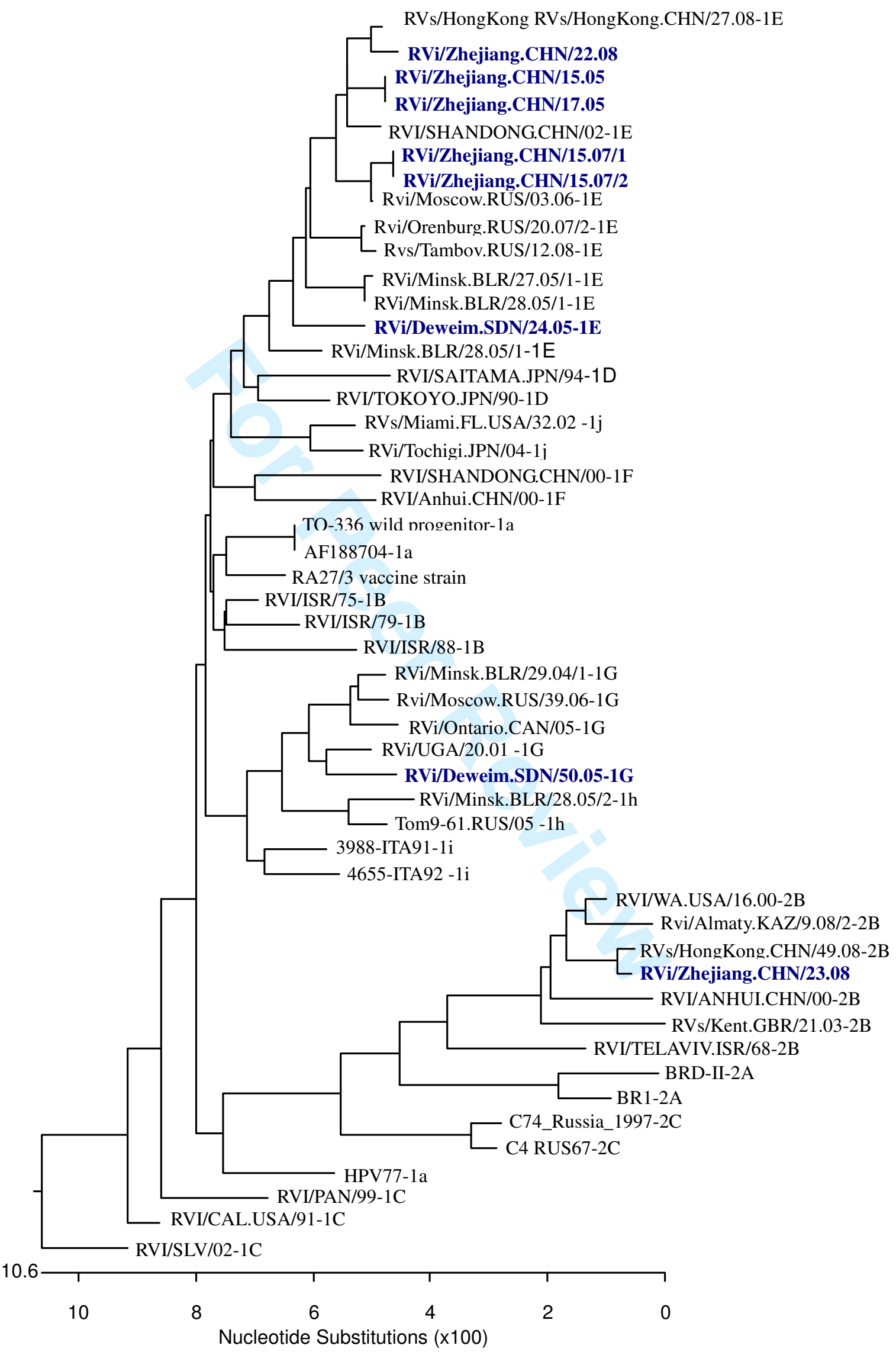




\section{Table I}

Comparison among the Rtime-SGE317, the Nested PCR-E860 and the Nested PCR-E317 assays

\begin{tabular}{|c|c|c|c|c|}
\hline \multicolumn{2}{|l|}{ Item } & Rtime-SGE317 & Nested PCR-E860 & Nested PCR-E317 \\
\hline \multicolumn{2}{|c|}{ Primer pair (100pmol/ul) } & $\mathrm{E} 1.7$ and $\mathrm{E} 1.8$ & $\begin{array}{l}\text { Ru1r and Ru2f } \\
\text { Ru3r and Ru4f }\end{array}$ & $\begin{array}{l}\mathrm{E} 1.5 \text { and } \mathrm{E} 1.6 \\
\mathrm{E} 1.7 \text { and } \mathrm{E} 1.8\end{array}$ \\
\hline \multicolumn{2}{|c|}{ Programme } & $\left.\begin{array}{l}50^{\circ} \mathrm{C} 2 \mathrm{~min} ; 95^{\circ} \mathrm{C} 15 \mathrm{~min} \\
94^{\circ} \mathrm{C} 15 \mathrm{sec} \\
55^{\circ} \mathrm{C} 20 \mathrm{sec} \\
72^{\circ} \mathrm{C} 20 \mathrm{sec} \\
82^{\circ} \mathrm{C} 5 \mathrm{sec} \text { Single } \\
95^{\circ} \mathrm{C} \text { 0sec } \\
65^{\circ} \mathrm{C} 1 \mathrm{~min} \\
95^{\circ} \mathrm{C} \text { 0sec Cont } \\
40^{\circ} \mathrm{C} 30 \text { sec }\end{array}\right\}$ Melting & $\left.\begin{array}{l}96^{\circ} \mathrm{C} 1 \mathrm{~min} \\
94^{\circ} \mathrm{C} 30 \mathrm{sec} \\
55^{\circ} \mathrm{C} 30 \mathrm{sec} \\
68^{\circ} \mathrm{C} 90 \mathrm{sec} \\
68^{\circ} \mathrm{C} 5 \mathrm{~min}\end{array}\right\} \quad 35$ Cycles & $\begin{array}{c}\text { Nested PCR } \\
\text { [Jin and Thomas, 2007] }\end{array}$ \\
\hline \multirow[b]{2}{*}{ Sensitivity } & Plasmid DNA & 200 copies/reaction & Not done & 2 copies/reaction \\
\hline & $\begin{array}{l}\text { Virus (Thomas) } \\
\text { cDNA dilutions }\end{array}$ & $10^{-3}$ & $10^{-2}$ & $10^{-4}$ \\
\hline \multicolumn{2}{|c|}{ Time for the process } & $1.5 \mathrm{~h}$ & $>4 h$ & $>4 h$ \\
\hline \multicolumn{2}{|c|}{ Suggested application } & Confirmation of $\mathrm{RV}$ isolates & Genotyping of RV isolates & $\begin{array}{l}\text { Confirmation of clinical } \\
\text { samples }\end{array}$ \\
\hline
\end{tabular}


Table II

Confirmation and quantitative detection of RV isolates in Vero cell culture

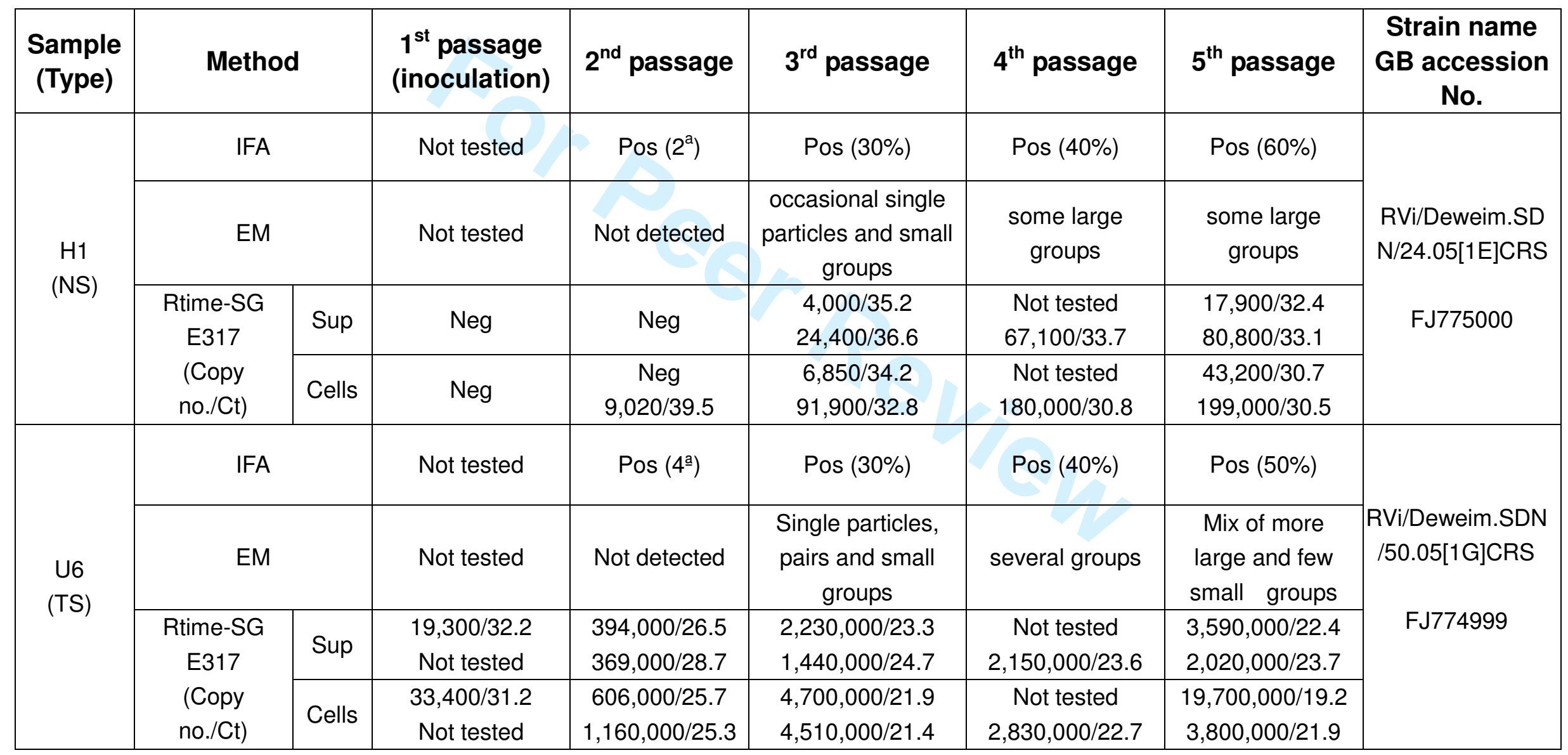




\begin{tabular}{|c|c|c|c|c|c|c|c|c|}
\hline $\begin{array}{l}\text { ZJ1 } \\
\text { (TS) }\end{array}$ & $\begin{array}{c}\text { Rtime-SG } \\
\text { E317 } \\
\text { (Copy no./Ct) }\end{array}$ & Mix & $\begin{array}{l}\text { Not } \\
\text { tested }\end{array}$ & $\begin{array}{c}1500 \sim 11900 / \\
26.6 \sim 27.0\end{array}$ & $\begin{array}{c}5800 \sim 32400 / \\
24.7 \sim 25.4\end{array}$ & $\begin{array}{c}3200 \sim 19800 / \\
25.6 \sim 26.3\end{array}$ & $\begin{array}{c}10000 \sim 46200 / \\
23.9 \sim 24.8\end{array}$ & $\begin{array}{c}\text { RVi/Zhejiang.CH } \\
\text { N/15.05 [1E] } \\
\text { GQ374567 }\end{array}$ \\
\hline $\begin{array}{l}\text { ZJ2 } \\
\text { (TS) }\end{array}$ & $\begin{array}{c}\text { Rtime-SG } \\
\text { E317 } \\
\text { (Copy no./Ct) }\end{array}$ & Mix & $\begin{array}{l}\text { Not } \\
\text { tested }\end{array}$ & $\begin{array}{c}1600 \sim 12100 / \\
26.5 \sim 26.7\end{array}$ & $\begin{array}{c}3900 \sim 23500 / \\
25.3 \sim 25.9\end{array}$ & $\begin{array}{c}3100 \sim 20900 / \\
25.6 \sim 26.3\end{array}$ & $\begin{array}{c}4900 \sim 29900 / \\
25.0 \sim 25.7\end{array}$ & $\begin{array}{c}\text { RVi/Zhejiang. } \mathrm{CH} \\
\text { N/17.05 [1E] } \\
\text { GQ374568 }\end{array}$ \\
\hline $\begin{array}{l}\text { ZJ3 } \\
\text { (TS) }\end{array}$ & $\begin{array}{c}\text { Rtime-SG } \\
\text { E317 } \\
\text { (Copy no./Ct) }\end{array}$ & Mix & $\begin{array}{l}\text { Not } \\
\text { tested }\end{array}$ & $\begin{array}{l}430 \sim 4500 / \\
28.5 \sim 28.8\end{array}$ & $\begin{array}{l}300 \sim 2610 / \\
29.0 \sim 29.5\end{array}$ & $\begin{array}{l}82 \sim 1500 / \\
30.5 \sim 30.9\end{array}$ & $\begin{array}{l}190 \sim 2470 / \\
29.6 \sim 30.3\end{array}$ & $\begin{array}{c}\text { RVi/Zhejiang.CH } \\
\text { N/15.07/1[1E] } \\
\text { GQ374569 }\end{array}$ \\
\hline $\begin{array}{l}\text { ZJ4 } \\
\text { (TS) }\end{array}$ & $\begin{array}{c}\text { Rtime-SG } \\
\text { E317 } \\
\text { (Copy no./Ct) }\end{array}$ & Mix & $\begin{array}{l}\text { Not } \\
\text { tested }\end{array}$ & $\begin{array}{l}120 \sim 1280 / \\
30.3 \sim 30.8\end{array}$ & $\begin{array}{l}230 \sim 2480 / \\
29.4 \sim 29.6\end{array}$ & $\begin{array}{l}200 \sim 2590 / \\
29.5 \sim 29.6\end{array}$ & $\begin{array}{l}110 \sim 1160 / \\
30.6 \sim 31.0\end{array}$ & $\begin{array}{c}\text { RVi/Zhejiang. } \mathrm{CH} \\
\text { N/15.07/2[1E] } \\
\text { GQ374570 }\end{array}$ \\
\hline $\begin{array}{l}\text { ZJ5 } \\
\text { (TS) }\end{array}$ & $\begin{array}{c}\text { Rtime-SG } \\
\text { E317 } \\
\text { (Copy no./Ct) }\end{array}$ & Mix & $\begin{array}{l}\text { Not } \\
\text { tested }\end{array}$ & $1220 / 31.5$ & $1270 / 31.4$ & Not tested & Not tested & $\begin{array}{c}\text { RVi/Zhejiang.CH } \\
\text { N/22.08 [1E] } \\
\text { GQ374571 }\end{array}$ \\
\hline $\begin{array}{l}\text { ZJ6 } \\
\text { (TS) }\end{array}$ & $\begin{array}{c}\text { Rtime-SG } \\
\text { E } 317 \\
\text { (Copy no./Ct) }\end{array}$ & Mix & $\begin{array}{c}\text { Not } \\
\text { tested }\end{array}$ & $306 / 33.7$ & $934 / 31.9$ & Not tested & Not tested & $\begin{array}{c}\text { RVi/Zhejiang.CH } \\
\text { N/23.08 [2B] } \\
\text { GQ374572 }\end{array}$ \\
\hline
\end{tabular}

a: Number of positive cells observed;

Sup: supernatant; Mix: mixture of supernatant and cells; Neg: negative; Pos: positive; NS: Nasal swab; TS: Throat swab

Numbers before or after" $\sim$ "indicate the range of Copy no./Ct for three triple on each sample.

Copy no./Ct of sample H1 and U6 were generated twice: Data in the upper row were quantified with water-diluted RV plasmid DNA. Otherwise were quantified with cell cDNA diluted-RV plasmid DNA. 